\title{
Immune System and Neurotrophic Factors in Autism
}

\author{
Elvan Iseri and Esra Guney \\ Gazi University Faculty of Medicine \\ Turkey
}

\section{Introduction}

Evidences related to the fact that there is a immunological functional disorder in autism are gradually increasing. Since immunological mechanisms play a role in the neuronal cell migration, axonal development and formation of synapses, it is mentioned that there is an immune - mediated inflammatory period exists (Bradstreet et al. 2007).

Central nervous system and immune system are systems which are in interaction with each other and which are complex and highly developed (Ashwood and Water 2004). Immune cells and molecules play an important role in forming the brain functions by affecting the cognitive and emotional processes. These molecules have various effects such as infection, inflammation and injury on neural tissues, the modulation of central nervous system response and systematic response. It is indicated that proinflammatory cytokines such as interleukin (IL) - 1, IL -6, IL - 12, interferon (IFN) gamma and tumor necrosis factor (TNF)alpha in particular directly affect the neural function and development by playing a role in the neurodevelopmental process. Applying the cytokines such as IFN - alpha, IL - 2, TNFalpha at therapeutical doses lead to the symptoms such as depression, sleep disorder, defects in cognitive functions, motivational change and decline in behavior of making research. It is reported that cytokines applied systematically may lead to increase in hypothalamus, hippocampus and nucleus accumbance and in noradrenergic, dopaminergic and serotenergic metabolism, and it may change the synaptic plasticity and therefore may affect the memory and learning processes (Ashwood et al. 2006). Findings which states that response of maternal immune to the infection, affect the fetal brain development through the increase in the cytokine level on circulation and which are collected from animal models support the role of immune system in the etiology of autism (Yamashita et al. 2003, Patterson 2002). It is mentioned that there is "abnormal" immune findings exists in $15-60 \%$ of the autistic children (Pardo et al 2005).

Two basic immune fuctional disorders in autism are associated with immune formation that includes autoimmunity and proinflammatory cytokines. The decline in the number of the CD4 lymphocyte numbers, the change of balance of T helper cell type 1(Th1)/ T helper cell type 2 (Th2) in the direction of Th2 and the response corruption of Th1 (corruption in cell mediated immunity), the decline in the T lymphocyte response against mitogens, the decline in the natural killer's functions and corruption shown by declined IgA level in humoral immunity are among immune system abnormalities indicated in autism (Cohly and Panja 2005, Careaga et al. 2010). 
It is put forward that infectious agents such as lead and measles virus are two basic environmental triggers and the environmental exposure to the lead affects the immune balance in a negative way. Although viruses trigger the process related to the autism, the basic devastating factor is the cytokines that are activated following the infection. In autism, inflammatory agents are generally related to the astrocytes and microglial cell activation. The existence of chronic microglial activation is indicated on the brains of autistic individuals. In autism, there is an increase in the proinflammatory chemokines and modulator cytokines (Cohly and Panja 2005). Detected increase in the level of proinflammatory cytokines such as IL - 6, TNF - alpha and monocyte chemoatractan protein $1(\mathrm{MCP}-1)$ in the brain samples and cerebrospinal fluid indicates that active neural inflammatory process is continuing in autism (Careaga et al. 2010). TNF- alpha is a strong immunomodulatory cytokine that is produced by macrophages and partly by active $\mathrm{T}$ cells. As well as its important function in the development of brain, it may have a role in the arrangement of glutamatergic transmission. It is put forward that TNF - alpha levels may be the indicator of possible inflammatory damage in autistic disorder (Chez et al. 2007). In the study performed by Jyonouchi and his collegues (2001) an increase in the serum of TNF alpha, IL-1 $\beta$ and IL-6 levels in autistic individuals is indicated and the existence of improper hereditary immune response in autism is mentioned. However, there is various study results in which no change is observed in the levels of serum of TNF - alpha in autistic disorder (Güney et al. 2008). In different study, increased serum IL - 12 and IFN - gamma levels are determined and no significant change is reported on IFN-alpha, IL-6, TNF-alpha serum levels (Singh 1996). It is indicated that there is a decline occur on anti - inflammatory cytokine levels such as IL - 10 and transforming growth factor beta (TGF- $\beta$ ) on autistic individuals. However, in all studies made in this field no consistent results in terms of cytokine patterns could be provided (Careaga et al. 2010).

Studies in which an increase on autoantibody unique to the brain is indicated support the autoimmune mechanism. In the serum of autistic individuals, autoantibodies against the proteins (myelin basic protein, neuron axon, filament protein, glial fibrillary acidic protein) limited by nervous system are observed (Schmitz and Rezaie 2008). In a study carried out by Singh and Rivas (2004), antibodies are determined against caudat nucleus (49\%) cerebral cortex $(18 \%)$ and cerebellum $(9 \%)$. It is put forward that these autoantibodies lead to symptoms observed in autism by corrupting neurological functions. Furthermore autoantibodies against receptor of serotonin are observed on autistic individuals (Singh et al. 1997).

In particular for HLA (human leukocyte antigen) gens, it is thought that many gens have relation with risk increase in the formation of certain autoimmune diseases. Different HLA haplotypes are also associated with neural developmental disorders like autism. Many HLA haplotype especially HLA - DR 4 is more frequently observed on autistic children than the general society. HLA genes are within a large genomic region called MHC (major histo compatibility complex). This region includes a vast of genes. One of these genes is the complement protein C4 gene which is important for natural immunity (Careaga et al. 2010). The relation of complement $4 \mathrm{~B}$ null allele with autism related to various autoimmune diseases was examined by Mostafa and Shehab (2010). It is indicated that in Egyptian children C4B null allele frequency is significantly higher. The relation of other gens such as macrophage migration inhibitor factor (MIF) gen and serine and threonine kinase $C$ gen, PRKCB with autism is indicated (Careaga et al. 2010). 
In many studies, a meaningful relation between familial autoimmunity and autism is found. It is associated with autistic characteristics such as the existence of the familial history of allergic/ autoimmune disease, regression and such as increased head circumference (Croen et al 2005, Molloy et al. 2006, Sacco et al. 2007). It is indicated that in the family of autistic individuals the number of autoimmune disease is much more (Comi et al. 1999). When family members with autoimmune disease goes up from 1 to 3 , autism risk will increase and probability ratio goes up from 1.9 to 5.5. The most common autoimmune diseases in these families are diabetes mellitus type 1, adult rheumatoid arthritis, hypothyroidism, celiac disease and systemic lupus erythematous. Yet in a study performed by Croen and his collegues (2005) the relation between the existence of autoimmune disease in mother (autoimmune diseased mother) and autism was supported. It is claimed that rather than a specific disorder in mother, a general immune function disorder will have relation with the increase in autism risk. (Careaga et al. 2010).

The fact that autoantibodies against the critical neural components of fetal brain structure of some mothers of autistic children is detected, shows the possible potential mechanism in the form of transmissing the antibodies to the fetus developing in pregnancy of the mother. It is thought that anti - fetal brain autoantibodies that are available nearly on $12 \%$ of the mothers of autistic children are connected to the neuronal targets during the formation and therefore they affect the neuronal formation. The view stating that antibodies isolated from the mother by animal models may affect the neural formation in the early period and therefore it may lead to behavioral changes (Careaga et al. 2010).

In line with the studies made in order to understand the neurobiology of autism, it is indicated that immunological factors also play a role in the etiopathogenesis of the disorder. Various findings such as the existence of antibodies against neural antigens and autoimmune disease history in the family support the possible role of immunological factors in autism. Although so far achieved symptoms make contribution to data that are related to the neurobiology of autism, they don't affect the diagnosis and treatment of autism. In the future, it is aimed to use these data in the separation of autism from other neurodevelopmental disorders and during the diagnosis and treatment process.

\section{Neurotrophic factors}

Several lines of evidence suggest that cytokines, growth factors and neurotrophic factors play particular signaling roles with in the brain to produce neurochemical, neuroendocrinological and behavioral changes (Hashimoto et al. 2003). Neurotrophic factors play an important role in the development of peripheral and central nervous system. Neurotrophic factors have an important function in the neurodevelopmental process for survival and differentiation of neurons, and regulation of their functions. Last findings showed us that the pathophysiology of autism is associated with neurotrophic factors. It is suggested that in some of the abnormality of neurotrophic factors may be implicated in mechanism associated with neural dysfunction in autism (Nelson et al 2006, Suzuki et al. 2007, Toyoda et al. 2007).

Neurotrophic factors comprise a range of different protein superfamilies. The well-known group among neurothrophic factors are neurotrophins. Nerve growth factor (NGF), brainderived growth factor (BDNF), neurotrophin (NT)-3, NT-4, NT-5 ve NT-6 are members of neurotrophin family. Other than the neurotrophins, neurotrophic superfamilies contain too many protein families such as neurokines (for example ciliary NTF (CNTF) and leukaemia 
inhibitory factor (LIF) ), insulin-like growth factors (for example, IGF-1 and IGF-2), fibroblast growth factors (for example FGF-1, FGF-2), as well as transforming growth factor$\beta$ (TGF- $\beta$ ) super family and epidermal growth factor superfamily (Barde 1990, Götz et al. 1994, Barbacid 1995, Nickl-Jockschat and Michel 2011).

The most important member of neurotrophin family having too many functions such as neuronal survival, target innervations and synaptogenesis in development of peripheral and central nerveus system is BDNF. All the neurotrophins bind with lower affinity to the p75 receptor and with high affinity to receptors of the tyrosine kinase family: NGF binds to TrkA, BDNF and NT-4 bind TrkB, NT-3 binds to TrkC (McKay et al. 1999). Neurotrophins perform their biological functions through such receptors. In neuron differentiation process, BDNF has too many roles such as neuronal survival, activity-dependent dendritic and axonal outhgrowth/branching, synapse formation and neuronal plasticity (reviewed in Polleux and Lauder 2004, Shieh ve Ghosh 1997). In various studies, the relationship of BDNF gene with autism is examined. Nishimura and his collegues (2007) determined increase of BDNF expression in autistic individuals. In different studies that followed, the probable role of BDNF gene mutation in autism pathogenesis is supported (Cheng et al. 2009). In a recent study by which significant increase of BDNF serum levels are determined in terms of autistic children, it is found that genetic variations of BDNF gene has no significant effect on risk of autism. However, a significant relationship is reported between neurotrophic thyrosine kinase, receptor, type $2=$ NTRK2 and autism (Correira et al. 2010).

In various studies, it is examined, whether there is any difference in the level of neurotrophic factor in serum and cerebrospinal fluid (CSF) of autistic children or not. In a study performed by Nelson and his collegues (2001), neonatal blood levels of neurotrophic factors are examined in autistic children and non autistic children with mental retardation. When compared with control group, in both groups, an important increase was observed in BDNF and neurotrophin 4/5 neonatal blood levels. In autism and a heterogenic group with cognitive functional defect, this result is very important in terms of indicating some neurotrophins' excessive express in peripheral blood taken in the early days of the life. However it is unknown whether these substances are also at high levels in prenatal life or not, or how long they remain at high levels in postnatal period. In their comprehensive study, Nelson and his collegues determined when compared with control group, that there is significant increase serum neurotrophin -4 and BDNF (the two TrkB ligands) in autism spectrum disorders and mental retardation without autism, but there were no changes with respect to NGF (trkA ligands) and neurotrophin-3 (TrkC ligands) levels. In line with these findings, it is suggested that trkB ligands are expressed or secreted at higher levels in the central nerveus system of children having autism or mental retardation during early infancy (reviewed in Polleux and Lauder 2004). It is suggested that the effect of BDNF and nörotrofin-4 on activity dependent dendritic outgrowth and branching (McAllister et al 1996, 1997), is related to the early and transient brain growth observed in autistic babies (Courchesne et al. 2003, reviewed in Polleux and Lauder 2004).

This increased level of BDNF expression and/or secretion is thought to have a relationship with the role of Methyl-CpG-binding protein $2(\mathrm{MeCP} 2)$ in the control of BDNF transcription (Chen et al. 2003) Mutation in MeCP2 gene is responsible for Rett Syndrome. It is shown that MeCP2 binds selectively to BDNF promoter III and performs the function of repressing the expression of BDNF gene (Shahbazian et al. 2002). The MeCP2 gene mutations, by having effect on BDNF expression and potentially dendritic differentiation in cortex, may become a risk factor for autism (reviewed in Polleux and Lauder 2004). For that 
purpose, in a study by which $\mathrm{MeCP} 2$ gene mutation in autistic individuals is researched, de novo mutation is found in two girls (Carney et al. 2003).

In a different study on children with autism spectrum disorders, the existence of autoantibodies against BDNF in the serum is shown together with the increase on the level of BDNF, and it is put forward that there is an interaction between BDNF and immune system (Connolly and et al. 2006). Morrison and Mason (1998) reported that the levels of increased BDNF and neurotrophin-4 resulted in the decline in the purkinje cell number in the existence of granular cells. Although it is suggested that changes in the levels of neurotrophin on autistic individuals may be the primary factor in the formation of autism, it is still not certain whether these changes are primary etiopathagenic mechanism or secondary reaction against cortical changes (Pardo ve Eberhart 2007).

By taking the changes determined in serum BDNF levels in autism spectrum disorders, Croen and his colleagues (2008) studied the usability of BDNF as an early biological marker for autism. In their evaluation of BDNF concentrations in mid-pregnancy and neonatal blood specimens, they found no differences between subjects with autism compared with subjects with mental retardation or with general population controls. It is reported that in critical period of early development, concentration of BDNF would not be a useful clinic biomarker for autism (Croen et al. 2008).

In a different study, the age-related changes of serum BDNF levels were studied and it was indicated that there were disturbances of BDNF level trajectories in autism cases. In healthy controls, the serum BDNF concentration was found to be increased over the first several years and decreased slightly after reaching the adult level. In the autism cases, mean levels were significantly lower in children between 0-9 ages compared to teenagers or adults, or to age-matched healthy controls, indicating a delayed BDNF increase with development. In the same study, circadian changes, but not seasonal changes, were found in serum levels of BDNF (Katoh-Semba et al. 2007).

There is a little number of studies that concentrated on CSF levels of neurotrophic factors. Riikonen and Vanhala (1999) investigated CSF NGF levels in children with infantile autism and children with Rett syndrome. It was indicated that mainly normal CSF NGF levels were found in autism, whereas there were low to negligible values in Rett Syndrome.

TGF- $\beta$ signaling, is related with too many biological processes that cover cell growth, differentiation and morphogenesis. By keeping in mind the key role of TGF- $\beta$ in mental development and in controlling immune responses, it was hyphothesized that TGF- $\beta 1$ could have a relationship with pathophysiology of autism. In various studies regarding autistic children and adults, it was determined that when compared with control group, the serum TNF- $\beta 1$ levels were significantly lower in the autistic patients (Okada et al.2007, Ashwood et al. 2008). It is suggested that this finding is in relationship with abnormalities in mental development and immune process regulation, which have been observed in autistic patients.

IGFs are peptides that regulate growth and differentiation as well as being synthesized in most tissues including the developing central nervous system (Bach and Rechler 1995, Jones and Clemmons 1995). It was shown that IGF 1 levels in CSF of autistic children were lower and this might play a role in the pathogenesis of autism (Vanhala et al. 2001). Because IGF 1 is important for the survival of Purkinje cells of the cerebellum, it is put forward that low concentrations of CSF IGF1 at an early stage might be linked with the pathogenesis in autism (Riikonen et al. 2006). 
EGF is a member of growth factors which play an important role in the cellular proliferation and the differentiation of the central and peripheral nervous system (Wong and Guillaud 2004). EGF has been suggested to be involved especially in the growth and survival of midbrain dopaminergic neurons (Alexi and Hefti 1993; Casper et al. 1991; Casper and Blum 1995). The most effective drugs in autism treatment are antipsychotics which block dopamin receptors; according to these findings it's suggested that there might be dopaminergic hyperactivity in autism pathophysiology. In a recent study, considering the role of EGF in mental development, it's relation with pathophysiology of autism was investigated and it was demonstrated that levels of EGF were significantly lower in adults with high functioning autism (Suzuki et al. 2007). Contrary to this finding, in a different study carried out on a pediatric autistic group, serum EGF levels in children with autism were significantly higher than those of age-matched normal healthy control subjects. This difference determined among and between adult and pediatric age groups in terms of serum EGF levels might be associated with possible developmental abnormality in the regulation of EGF expression. It can be expected that EGF levels may increase in early ages and begin to decrease as the autistic individual gets older (Işeri et al. 2011).

Due to the fact that behavioral symptoms and functional impairment degree are variable, autism is defined as the heterogeneous symptom cluster that has different etiology and pathology. Although phenotypic heterogeneity is the biggest obstacle in front of the research carried out that are oriented to defining the etiology of the autism, the fact that research techniques related to the biological factors are increased in the recent period and that research made on such field has become widespread, is promising. Due to their key roles during the neurodevelopment, neurotrophic factors have become one of the issues focused on research carried out that are oriented to determining the etiopathogenesis of autism. In most of the studies, significant differences were detected on the levels of serum neurotrophic factor. Studies performed up to now showed that neurotrophic factors could play a role in the pathophysiology of autism. However, it is necessary to integrate the findings of those studies above with new studies investigating the anatomical and functional changes on central nervous system of autistic patients in the future.

\section{References}

Alexi T, Hefti F (1993) Trophic actions of transforming growth factor alpha on mesencephalic dopaminergic neurons developing in culture. Neuroscience, 55 (4): 903-918.

Ashwood P, Water JV (2004) Is autism an autoimmune disease? Autoimmunity Reviews, 57:557-562.

Ashwood P, Wills S, Water JV (2006) The immune response in autism: a new frontier for autism research. Journal of Leukocyte Biology, 80: 1-15.

Ashwood P, Enstrom A, Krakowiak P, Hertz-Picciotto I, Hansen RL, Croen LA et al. (2008)Decreased transforming growth factor beta 1 in autism: a potential link between immune dysregulation and impairment in clinical behavioral outcomes. Neuroimmunol, 204:149-153.

Bach LA, Rechler MM (1995) Insulin like growth factor binding proteins. Diabete Rev, 3: 3861. 
Barbacid M (1995) Neurotrophic factors and their receptors. Curr Opin Cell Biol, 7:148155.

Barde YA (1990) The nerve growth factor family. Prog Growth Factor Res, 2: 237-248

Bradstreet JJ, Smith S, Granpeesheh D, El-Dahr JM, Rossignol (2007) Spironolactone might be a desirable immunologic and hormonal intervention in autism spectrum disorders. Med Hypotheses, 68(5): 979-87.

Careaga M, Water JV, Ashwood P (2010) Immune dysfunction in autism: A pathway to treatment. Neurotherapeutics: The Journal of American Society for Experimental NeuroTherapeutics, 7: 283-292.

Carney RM, Wolpert CM, Ravan SA, Shahbazian M, Ashley-Koch A, Cuccaro ML et al (2003) Identification of MeCP2 mutations in a series of females with autistic disorder. Pediatr Neurol, 28: 205-11.

Casper D, Blum M (1995) Epidermal growth factor and basic fibroblast growth factor protect dopaminergic neurons from glutamate toxicity in culture. J Neurochem, 65 (3): 1016-1026.

Casper D, Mytilineou C, Blum M (1991) EGF enhances the survival of dopamine neurons in rat embryonic mesencephalon primary cell culture. J. Neurosci. Res, 30 (2): 372-381.

Chen WG, Chang Q, Lin Y, Meissner A, West AE, Griffith EC et al. (2003) Derepression of BDNF transcription involves calcium-dependent phosphorylation of MeCP2. Science, 302: 885-889.

Cheng L, Ge Q, Xiao P, Sun B, Ke X, Bai Y ve ark (2009) Association study between BDNF gene polymorphism and autism by three-dimensional gel-based microarray. Int J Mol Sci, 10(6): 2487-2500.

Chez MG, Dowling T, Patel PB, Khanna P, Kominsky M (2007) Elavation of Tumor Necrosis Factor-alpha in Cerebrospinal Fluid of Autistic Children. Pediatr Neurol, 36: 361365.

Cohly HH, Panja A (2005) Immunological dfindings in autism. Int Rev Neurobiol, 71: 317341.

Comi AM, Zimmerman AW, Frye VH, Law PA, Peeden JN (1999) Familial clustering of autoimmune disorders and evaluation of medical risk factors in autism. J Child Neurol, 14: 388-394.

Connolly AM, Chez M, Streif EM, Keeling RM, Golumbek PT, Kwon JM et al (2006) Brainderived neurotrophic factor and autoantibodies to neural antigens in sera of children with autistic spectrum disorders, Landau-Kleffner syndrome, and epilepsy. Biol Psychiarty, 59:354-63.

Correira CT, Coutinho AM, Sequeira AF, Sousa IG, Lourenço Venda L, Almeida JP et al. (2010) Increased BDNF levels and NTRK2 gene association suggest a disruption of BDNF/TrkB signaling in autism. Genes, Brain and behavior, 9(7): 841-8.

Courchesne E, Carper R, Akshoomoff N (2003) Evidence of brain overgrowth in the first year of life in autism. JAMA, 290:337-344.

Croen LA, Grether JK, Yoshida CK, Odouli R, Van de Water J (2005) Maternal autoimmune diseases, asthma and allergies, and childhood autism spectrum disorders: A casecontrol study. Archives of Pediatrics and Adolescent Medicine, 159: 151-157. 
Croen LA, Goines P, Braunschweig D, Yolken R, Yoshida CK, Grether JK et al. (2008) Brainderived neurotrophic factor and autism: Maternal and infant peripheral blood levels in the early markers for autism (EMA) study. Autism Research, 1:130-137

Götz R, Köster R, Winkler C, Raulf F, Lottspeich F, Schartl M et al (1994) Neurotrophin-6 is a new member of the nerve growth factor family. Nature, 372:266-269.

Güney E, İşeri E, Atak A, Aral A, Bodur Ş, Şener Ş (2008) Otistik bozukluğu olan çocuklarda TNF-alfa düzeyi. Türkiye' de Psikiyatri, 10(2): 52-56.

Hashimoto K, Shimizu E, Komatsu N, Nakazato M, Okamura N, Watanabe H, et al. (2003) Increased levels of serum basic fibroblast growth factor in schizophrenia. Psychiatry Research, 120:211-218.

Işeri E, Güney E, Ceylan MF, Yücel A, Aral A, Bodur S et al. (2011) Increased serum levels of epidermal growth factor in children with autism. J Autism Dev Disord, 41(2): 23741.

Jones JI, Clemmons DR (1995) Insulin like growth factors and their binding protein: biological actions. Endocr Reviews 16: 3-34.

Jyonouchi H, Sun S, Le S (2001) Proinflammatory and regulatory cytokine production associated with innate and adaptive immune responses in children with autism spectrum disorders and developmental regression. J Neuroimmunol, 120: 170-9.

Katoh-Semba R, Wakako R, Komori T, Shigemi H, Miyazaki N, Ito H et al. (2007) Agerelated changes in BDNF protein levels in human serum: differences between autism cases and normal controls. Int J Dev Neurosci, 25:367-372.

McAllister AK, Katz LC, Lo DC (1996) Neurotrophin regulation of cortical dendritic growth requires activity . Neuron, 17: 1057-1064.

McAllister AK, Katz LC, Lo DC (1997) Opposing roles for endogenous BDNF and NT-3 in regulating cortical dendritic growth. Neuron, 18:767-778.

McKay SE, Purcell AL, Carew TJ (1999) Regulation of synaptic function by neurotrophic factors in vertebrates and intervertebrates:Implications for development and learning.Learn Mem, 6:193-215.

Molloy CA, Morrow AL, Meinzen-Derr J, Dawson G, Bernier R, Dunn M et al (2006) Familial autoimmune thyroid disease as a risk factor for regression in children with autism spectrum disorder: ACPEA study. J Autism Dev Disord, 36: 317-324.

Morrison ME, Mason CA (1998) Granule neuron regulation of purkinje cell development: Striking a balance between neurotrophin and glutamate signaling. Journal of neuroscience, 18; 3563-3573.

Mostafa GA, Shehab AA (2010) The link of C4B null allele to autism and to a family histoy of autoimmunity in Egyptian autistic children. J Neuroimmunol, 223 (1-2): 115-9.

Nelson PG, Kuddo T, Song EY, Dambrosia JM, Kohler S, Satyanarayana G et al. (2006) Selected neurotrophins, neuropeptides, and cytokines: developmental trajectory and concentrations in neonatal blood of children with autism or Down syndrome. Int J Dev Neurosci, 24(1):73-80.

Nelson KB, Grether JK, Croen LA, Dambrosia JM, Dickens BF, Jelliffe LL et al. (2001) Neuropeptides and neurotrophins in neonatal blood of children with autism or mental retardation. Ann neurol, 49: 597-606.

Nickl-Jockschat T, Michel TM (2011) The role of neurotrophic factors in autism. Mol Psychiatry, 16: 478-490. 
Nishimura K, Nakamura K, Anitha A, Yamada K, Tsujii M, Iwayama Y ve ark (2007) Genetic analyses of the brain -derived neurotrophic factor (BDNF) gene in autism. Biochem Biophys Res Commun, 356 (1):200-6.

Okada K, Hashimoto K, Iwata Y, Nakamura K, Tsujii M, Tsuchiya KJ et al. (2007) Decreased serum levels of transforming growth factor $\beta 1$ in patients with autism. Prog Neuropsychopharmacol Biol Psychiatry, 31(1): 187-190.

Pardo CA, Eberhart CG (2007) The neurobiology of autism. Brain Pathol, 17: 434-447.

Pardo CA, Vargas DL, Zimmerman AW (2005) Immunity, neuroglia and neuroinflammation in autism. International Review of Psychiatry, 17 (6): 485-495.

Patterson PH (2002) Maternal infection: window on neuroimmuneinteractions in fetal brain development and mental ilness. Curr Opin Neurobiol, 12: 115-118.

Polleux F, Lauder JM (2004) Toward a developmental neurobiology of autism. Mental Retardation and Developmental Disabilities Research Review, 10: 303-317.

Riikonen R, Vanhala R (1999) Levels of cerebrospinal fluid nerve-growth factor differ in infantile autism and Rett Syndrome. Dev Med Child Neurol, 41(3): 148-52.

Riikonen R, Makkonen I, Vanhala R, Turpeinen U, Kuikka J, Kokki H (2006) Cerebrospinal fluid insulin-like growth factors IGF1 and IGF2 in infantile autism. Dev Med Child Neurol 48(9): 751-5.

Sacco R, Militerni R, Frolli A, Bravaccio C, Gritti A, Elia M et al (2007) Clinical, morphological, and biochemical correlates of head circumference in autism. Biol Psychiatry, 62(9): 1038-47.

Schmitz C, Rezaie P (2008) The neuropathology of autism: where do we stand? Neuropathology and Applied Neurobiology, 34: 4-11.

Shahbazian M, Young J, Yuva-Paylor L, Spencer C, Antalffy B, Noebels J et al. (2002) Mice with truncated $\mathrm{MeCP} 2$ recapitulate many Rett syndrome features and display hyperacetylation of histone H3. Neuron, 35: 243-254.

Shieh PB, Ghosh A (1997) Neurotrophins: new roles for a seasoned cast. Current Biology, 7: 627-630.

Singh VK (1996) Plasma increase of interleukin-12 and interferon-gamma.Pathological significance in autism. J Neuroimmunol, 66:143-145.

Singh VK, Rivas WH (2004) Prevalence of serum antibodies to caudate nucleus in autistic children. Neuroscience Letters, 355: 53-56.

Singh VK, Singh EA, Warren RP (1997) Hyperserotoninemia and serotonin receptor antibodies in children with autism but not mental retardation. Biol Psychiatry, 41: 753-755.

Suzuki K, Hashimato K, Iwata Y, Nakamura K, Tsujii M, Tsuchiya KJ et al.(2007) Decreased serum levels of epidermal growth factor in adult subjects with high-functioning autism. Biol Psychiatry, 62:267-269.

Toyoda T, Nakamura K, Yamada K, Thanseem I, Anitha A, Suda S, et al. (2007) SNP analyses of growth factor genes EGF, TGF $\beta-1$, and HGF reveal haplotypic association of EGF with autism. Biochemical and Biophysical Research Communications, 360(4): 715-720.

Vanhala R, Turpeinen U, Riikonen R (2001) Low levels of insulin-like growth factor-I in cerebrospinal fluid in children with autism. Dev Med Child Neurol, 43: 614-616.

Wong RW, Guillaud L (2004) The role of epidermal growth factor and its receptors in mammalian CNS. Cytokine Growth Factor Rev, 15:147-156. 
Yamashita Y, Fujimoto C, Nakajima E, Isagai T, Matsuishi T (2003) Possible association between congenital cytomegalovirus infection and autistic disorder. J Autism Dev Disord, 33: 455-459. 


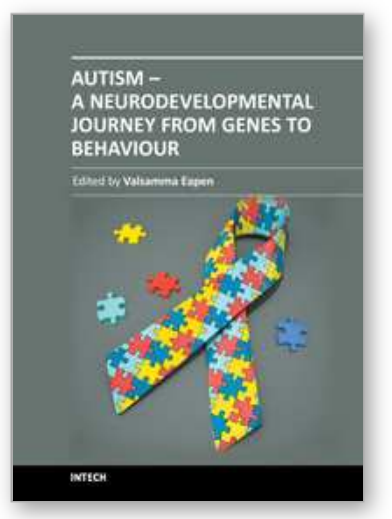

\author{
Autism - A Neurodevelopmental Journey from Genes to Behaviour \\ Edited by Dr. Valsamma Eapen
}

ISBN 978-953-307-493-1

Hard cover, 484 pages

Publisher InTech

Published online 17, August, 2011

Published in print edition August, 2011

The book covers some of the key research developments in autism and brings together the current state of evidence on the neurobiologic understanding of this intriguing disorder. The pathogenetic mechanisms are explored by contributors from diverse perspectives including genetics, neuroimaging, neuroanatomy, neurophysiology, neurochemistry, neuroimmunology, neuroendocrinology, functional organization of the brain and clinical applications from the role of diet to vaccines. It is hoped that understanding these interconnected neurobiological systems, the programming of which is genetically modulated during neurodevelopment and mediated through a range of neuropeptides and interacting neurotransmitter systems, would no doubt assist in developing interventions that accommodate the way the brains of individuals with autism function. In keeping with the multimodal and diverse origins of the disorder, a wide range of topics is covered and these include genetic underpinnings and environmental modulation leading to epigenetic changes in the aetiology; neural substrates, potential biomarkers and endophenotypes that underlie clinical characteristics; as well as neurochemical pathways and pathophysiological mechanisms that pave the way for therapeutic interventions.

\title{
How to reference
}

In order to correctly reference this scholarly work, feel free to copy and paste the following:

Elvan Iseri and Esra Guney (2011). Immune System and Neurotrophic Factors in Autism, Autism - A Neurodevelopmental Journey from Genes to Behaviour, Dr. Valsamma Eapen (Ed.), ISBN: 978-953-307-4931, InTech, Available from: http://www.intechopen.com/books/autism-a-neurodevelopmental-journey-fromgenes-to-behaviour/immune-system-and-neurotrophic-factors-in-autism

\section{INTECH}

open science | open minds

\section{InTech Europe}

University Campus STeP Ri

Slavka Krautzeka 83/A

51000 Rijeka, Croatia

Phone: +385 (51) 770447

Fax: +385 (51) 686166

www.intechopen.com

\section{InTech China}

Unit 405, Office Block, Hotel Equatorial Shanghai

No.65, Yan An Road (West), Shanghai, 200040, China 中国上海市延安西路65号上海国际贵都大饭店办公楼 405 单元

Phone: +86-21-62489820

Fax: +86-21-62489821 
(C) 2011 The Author(s). Licensee IntechOpen. This chapter is distributed under the terms of the Creative Commons Attribution-NonCommercialShareAlike-3.0 License, which permits use, distribution and reproduction for non-commercial purposes, provided the original is properly cited and derivative works building on this content are distributed under the same license. 